\title{
Metabolism of the Herbicide Orbencarb in Soybean, Wheat, Corn and Crabgrass Seedlings *
}

\author{
Mitsumasa IKeda, Tadaaki Unal and Chojiro Tomizawa** \\ Life Science Research Institute, Kumiai Chemical Industry Co. Ltd., \\ Kikugawa-cho, Ogasa-gun, Shizuoka 439, Japan \\ **National Institute of Agro-Environmental Sciences, Yatabe-machi, \\ Tsukuba-gun, Ibaraki 305, Japan
}

\section{Introduction}

Orbencarb (S-2-chlorobenzyl $N, N$-diethylthiocarbamate) is a pre-emergence herbicide for the control of weeds in upland crops such as soybean and corn plants. It is a 2-chloro isomer of benthiocarb which has been widely used for the control of weeds in paddy fields.

Several studies on soil ${ }^{8)}$ and plant metabolism ${ }^{9,10.20)}$ have been conducted in relation to the fate of orbencarb in the environment. Soybean plant converted the 2-chlorobenzyl moiety of orbencarb sulfoxide to $S$-(2-chlorobenzyl)cysteine derivatives as major pathways ${ }^{21)}$. These<smiles>NC(CSCc1ccccc1Cl)C(=O)O</smiles>

$S$-(2-Chlorobenzyl)-L-cysteine (2-Cl-BZ-Cys)<smiles>O=C(O)C(CSCc1ccccc1Cl)NCc1ccccc1</smiles>

$S$-(2-Chlorobenzyl) $-N$-malonyl$\mathrm{L}-$ cysteine (2-Cl-BZ-Ma-Cys) studies showed that the metabolic fate of orbencarb was similar to that of benthiocarb ${ }^{12,16)} \mathrm{ex}$ cept for the identification of $S$-(2-chlorobenzyl)glutathione, $S$-(2-chlorobenzyl)-L-cysteine, $S$-(2chlorobenzyl)- $N$-malonyl-L-cysteine and their sulfoxides. In the present study, the translocation and metabolism of orbencarb absorbed by the roots of soybean, wheat, corn and crabgrass seedlings are described.

\section{Materials and Methods}

\section{Radioactive orbencarb}

${ }^{14} \mathrm{C}$-Orbencarb labeled uniformly on the ben-<smiles>NC(C[S+]([O-])Cc1ccccc1Cl)C(=O)O</smiles>

$S$-(2-Chlorobenzyl)-L-cysteine sulfoxide

(2-Cl-BZ-Cys sulfoxide)

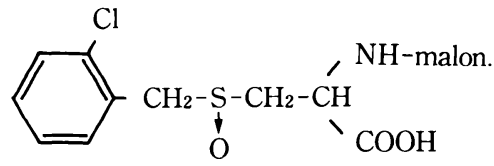

$S$ - (2-Chlorobenzyl) $-N$-malonyl$\mathrm{L}-$ cysteine sulfoxide (2-Cl-BZ-Ma-Cys sulfoxide)

Fig. 1 Chemical structures of $S$-(2)-chlorobenzyl)-1-cysteine derivatives Malon. indicates malonic acid Parentheses indicate the designation of chemicals

* This work was reported at the 11th Annual Meeting of the Pesticide Science Society of Japan, 1986 
zene ring was used in this study ${ }^{9}$. The specific activity was $2.40 \mathrm{mCi} / \mathrm{mmol}$ and the radiochemical purity was $99.8 \%$.

\section{Possible metabolites of orbencarb}

Chemical names, designations, and $R f$ values of orbencarb and its derivatives for identification of the metabolites were described in our earlier reports ${ }^{8,9,21)}$. Figure 1 shows the chemical structures and designations of $S$-(2-chlorobenzyl)-Lcysteine derivatives used in this experiment.

\section{Plants}

As tolerant upland crops to orbencarb, seedlings of soybean (Glycine max var. Enray) at the first foliage leaf stage, wheat (Triticum spp.) at the 4th leaf stage and corn (Zea mays L.) at the 3rd leaf stage were used, while seedlings of crabgrass (Digitaria adscendes Henr.) at the 4th leaf stage were used as an upland weed susceptible to orbencarb $^{20)}$.

The seedlings were grown in Kasugal's nutrient solution $\left[\mathrm{NH}_{4} \mathrm{NO}_{3} 57.5 \mathrm{mg}, \mathrm{KCl} 43.0 \mathrm{mg}, \mathrm{MgSO}_{4}\right.$ $120.0 \mathrm{mg}, \mathrm{KH}_{2} \mathrm{PO}_{4} 38.3 \mathrm{mg}, \mathrm{Ca}\left(\mathrm{NO}_{3}\right)_{2} 117.0 \mathrm{mg}, 6 \%$ $\left.\mathrm{FeCl}_{3} 2.5 \mathrm{ml}, \mathrm{MnCl}_{2} 0.4 \mathrm{mg} / 1\right]$.

\section{Plant treatment}

${ }^{14} \mathrm{C}$-Orbencarb (250 $\mu \mathrm{g}, 2.32 \mu \mathrm{Ci}$ ) was dissolved in $100 \mathrm{ml}$ of $1: 2$ diluted Kasugal's nutrient solution to make a $2.5 \mathrm{ppm}$ orbencarb solution. Only the root portions of three seedlings of each species (soybean $10.0 \mathrm{~g}$, wheat $2.3 \mathrm{~g}$, corn $3.6 \mathrm{~g}$, crabgrass $1.8 \mathrm{~g}$ ) were immersed in the solution.

The seedlings were cultivated in the ${ }^{14} \mathrm{C}$ orbencarb solution for $96 \mathrm{hr}$ at $22-24{ }^{\circ} \mathrm{C}$ with 12 $\mathrm{hr}$ daylength under $20 \mathrm{klx}$ light intensity. They were sampled 2, 6, 24 and $96 \mathrm{hr}$ after the treatment and their roots were washed with water. One seedlig of each species was applied to autoradiography to examine the translocation of radioactivity in the plant.

\section{Analysis of metabolites}

Two seedlings of each plant species, $96 \mathrm{hr}$ after treatment, were used to determine orbencarb and its metabolites. Culture solutions were also analyzed at the same time to determine the radioactivity. The procedures for the analysis of radioactive metabolites are the same as previ- ously described ${ }^{9,21)}$.

\section{Results}

\section{Translocation of radioactivity in plants}

As shown in Fig. $2,{ }^{14} \mathrm{C}$-orbencarb in the culture solution was absorbed by the roots and translocated throughout the entire plants. In all plant species, radioactivity in the root was highest in the seedlings. The degree of radiocarbon movement to the newly developed leaf in soybean seedlings was greater than that in wheat, corn or crabgrass.

Seedlings of soybean, wheat, corn and crabgrass respectively absorbed 59.2, 22.6, 19.0 and $8.3 \%$ of the applied radioactivity $96 \mathrm{hr}$ after treatment, and their concentration were 14.0, 25.3,12.8 and $11.5 \mathrm{ppm}$ (orbencarb equivalent/fresh weight). "The culture solution contained the unabsorbed orbencarb.

\section{Identification of metabolites in plants}

Metabolites in plants which were detected 96 $\mathrm{hr}$ after treatment are shown in Table 1. Analysis of dichloromethane- and water-soluble fractions showed that the greater part of radioactivity in the dichloromethane fraction was due to orbencarb, and a main metabolite in the water-soluble fraction was $S$-(2-chlorobenzyl)-L-cysteine ( $2-\mathrm{Cl}$ BZ-Cys). Sixteen metabolites were tentatively identified by two dimensional co-TLC with the authentic compounds as free or methyl esters. Among them, S-(2-chlorobenzyl)-L-cysteine, S-(2chlorobenzyl)- $N$-malonyl-L-cysteine (2-Cl-BZMa-Cys), $S$-(2-chlorobenzyl)- $N$-malonyl-L-cysteine sulfoxide (2-Cl-BZ-Ma-Cys sulfoxide), 2-chlorobenzyl alcohol (2-Cl-BZ alc), 2-chlorobenzoic acid (2-Cl-benzoic acid) and S-2-chlorobenzyl $\mathrm{N}$ ethylthiocarbamate (monodesethyl-orbencarb) were identified as major metabolites. 2-Cl-BZ alc and 2-Cl-benzoic acid were also detected as glycoside conjugates in water-soluble fractions.

The remaining ten metabolites were identified as relatively minor metabolites. They were orbencarb sulfoxide, S-2-chlorobenzyl thiocarbamate (didesethyl-orbencarb), S-2-chlorobenzyl $N$ - 

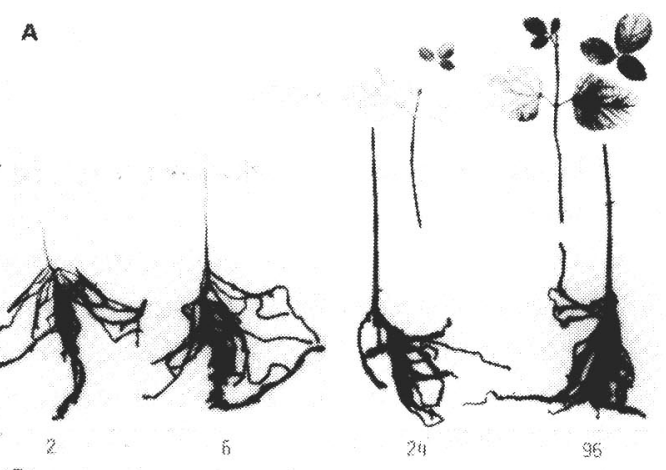

8
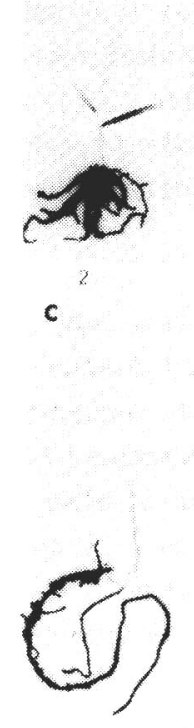

D

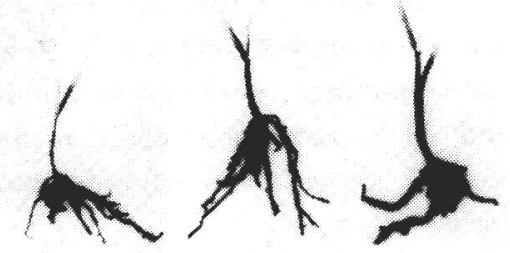

24

96

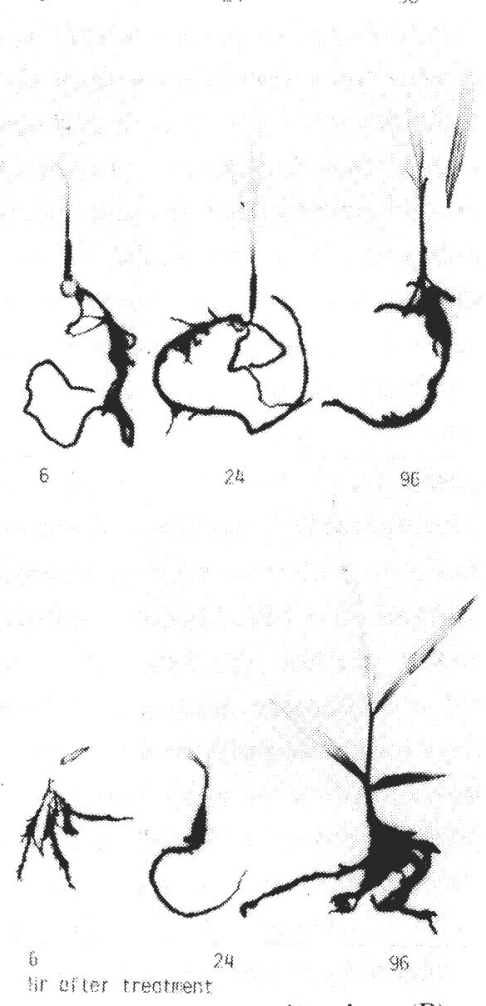

Ir efter treatert? ethyl- $N$-vinylthiocarbamate $\left(N-\mathrm{CH}=\mathrm{CH}_{2}\right.$-orbencarb), S-2-chlorobenzyl $N$-ethyl- $N$ - $\beta$-hydroxyethylthiocarbamate ( $\mathrm{N}-\mathrm{CH}_{2} \mathrm{CH}_{2} \mathrm{OH}$-orbencarb), $S$-(2-chloro-4-hydroxybenzyl) $\mathrm{N}, \mathrm{N}$-diethylthiocarbamate (4-OH-orbencarb), S-(2-chloro-5-hydroxybenzyl) $\mathrm{N}, \mathrm{N}$-diethylthiocarbamate $(5-\mathrm{OH}$ orbencarb), methyl 2-chlorobenzylsulfide ( $2-\mathrm{Cl}$ BZ-SCH${ }_{3}$ ), methyl 2-chlorobenzylsulfoxide ('2$\mathrm{Cl}-\mathrm{BZ}-\mathrm{S}(\mathrm{O}) \mathrm{CH}_{3}$ ), methyl 2-chlorobenzylsulfone (2-Cl-BZ-SO $\mathrm{S}_{2} \mathrm{CH}_{3}$ ) and 2-chlorobenzylsulfonic acid (2-Cl-BZ-SO $\left.{ }_{3} \mathrm{H}\right)$.

Figure 3 shows the degrees of biochemical conversion from orbencarb to $S$-(2-chlorobenzyl)-Lcysteine derivatives, and the sum of $2-\mathrm{Cl}-\mathrm{BZ}$ alc and 2 -Cl-benzoic acid in four plant species. Formation of $S$-(2-chlorobenzyl)-L-cysteine derivatives was quantitatively different among the plant species; conversion to those was 19.3, 12.5, 10.1 and $3.3 \%$ for soybean, wheat, corn and crabgrass, respectively, and the ratios were $5.8: 3.8: 3.1: 1.0$. No great difference was oberved in the amounts of metabolites such as $2-\mathrm{Cl}-\mathrm{BZ}$ alc and 2-Cl-benzoic acid.

\section{Discussion}

The metabolism of herbicidal thiocarbamates, their sulfoxides, and sulfones has been studied by several researchers ${ }^{1-7,11-19)}$. Those studies showed that thiocarbamates were oxidized to their sulfoxides and sulfones and then conjugated with glutathione at the $N, N$-dialkylcarbamoyl moiety of the sulfoxides ${ }^{1,2,19)}$ and sulfones ${ }^{6)}$ to form $S$ $(N, N$-dialkylcarbamoyl)glutathione and alkylsulfenic acid. The alkylsulfenic acid was further oxidized in part to the corresponding sulfonic acid $^{19)}$, and it was expected that 2 -Cl-BZ- $\mathrm{SO}_{3} \mathrm{H}$ might appear as a main metabolite for orbencarb; but actually the expected 2-Cl-BZ- $\mathrm{SO}_{3} \mathrm{H}$ appeared only as a minor metabolite (less than $0.2 \%$ of the radioactivity in plants). On the other hand, $S-(2$ chlorobenzyl)-L-cysteine derivatives and 2-Cl-BZ alc were detected as the major metabolites in this study, and were also found as major metabolites of orbencarb sulfoxide absorbed by stems of soybean plants ${ }^{21)}$. The result suggested that a part of 
Table 1 Percent of orbencarb and its metabolites in soybean, wheat, corn and crabgrass seedlings 96 hr after treatment

\begin{tabular}{|c|c|c|c|c|c|}
\hline Fractions & Metabolites & $\begin{array}{l}\text { Soybean } \\
\text { (1/1) }\end{array}$ & $\begin{array}{l}\text { Wheat } \\
(1 \%)\end{array}$ & $\begin{array}{l}\text { Corn } \\
\text { ('少) }\end{array}$ & $\begin{array}{c}\text { Crabgrass } \\
\text { (ו) }\end{array}$ \\
\hline \multicolumn{2}{|c|}{ Dichloromethane-soluble } & 65.3 & 42.1 & 51.1 & 64.8 \\
\hline & Orbencarb & 43.7 & 31.7 & 36.7 & 54.4 \\
\hline & Orbencarb sulfoxide & 0.1 & 0.3 & 0.1 & 0.2 \\
\hline & Monodesethyl-orbencarb & 2.2 & 1.9 & 2.9 & 3.2 \\
\hline & Didesethyl-orbencarb & $<0.1$ & $<0.1$ & $<0.1$ & - \\
\hline & $\mathrm{N}-\mathrm{CH}=\mathrm{CH}_{-}$-orbencarb & 0.5 & 0.5 & 0.5 & 0.6 \\
\hline & $\mathrm{N}-\mathrm{CH}, \mathrm{CH}, \mathrm{OH}$-orbencarb & 0.1 & 0.1 & - & - \\
\hline & 4-OH-orbencarb & $<0.1$ & 0.1 & 0.8 & 0.3 \\
\hline & 5-OH-orbencarb & 0.1 & 0.4 & 0.8 & 0.5 \\
\hline & $2 \cdot \mathrm{Cl}-\mathrm{BZ}$ alc & 0.4 & $<0.1$ & 0.2 & 0.1 \\
\hline & 2-Cl-benzoic acid & 0.7 & 1.3 & 0.8 & 0.6 \\
\hline & $2-\mathrm{Cl}-\mathrm{BZ}-\mathrm{SCH}_{3}$ & 0.2 & 0.1 & 0.8 & 0.7 \\
\hline & 2-Cl-BZ-S(O)CH & 0.1 & $<0.1$ & 0.1 & $<0.1$ \\
\hline & $2-\mathrm{Cl}-\mathrm{BZ}-\mathrm{SO}_{2} \mathrm{CH}_{3}$ & $<0.1$ & $<0.1$ & 0.4 & 0.1 \\
\hline & 2-Cl-BZ-Ma-Cys & 5.1 & 0.4 & 0.7 & 0.3 \\
\hline & 2-Cl-BZ-Ma-Cys sulfoxide & 4.8 & 0.7 & 1.3 & 0.6 \\
\hline & Unknown-1 & 0.3 & 0.6 & 0.4 & 0.5 \\
\hline & " 2 & $<0.1$ & - & - & - \\
\hline & $\begin{array}{ll}1 & -3\end{array}$ & 0.1 & 0.3 & 0.5 & $<0.1$ \\
\hline & Others & 6.9 & 3.7 & 4.1 & 2.7 \\
\hline \multirow[t]{8}{*}{ Water-soluble } & 140 or & 27.9 & 44.5 & 33.5 & 36.5 \\
\hline & $\begin{array}{l}\text { C-Agrycones } \\
\text { 2-Cl-BZ alc }\end{array}$ & 5.1 & 2.1 & 6.0 & 1.9 \\
\hline & 2-Cl-benzoic acid & 0.8 & 4.3 & 4.0 & 3.3 \\
\hline & Unknowns & 3.6 & 14.9 & $7: 7$ & 6.0 \\
\hline & 2-Cl-BZ-Cys & 6.1 & 10.6 & 7.7 & 0.9 \\
\hline & 2-Cl-BZ-Ma-Cys & 3.3 & 0.8 & 0.4 & 1.5 \\
\hline & $2-\mathrm{Cl}-\mathrm{BZ}-\mathrm{SO}_{33} \mathrm{H}$ & 0.1 & 0.2 & 0.1 & 0.2 \\
\hline & Aqueous & 8.9 & 11.6 & 7.6 & 22.7 \\
\hline \multicolumn{2}{|l|}{ Bound residue } & 6.8 & 13.4 & 15.4 & 8.7 \\
\hline \multicolumn{2}{|l|}{ Total } & 100.0 & 100.0 & 100.0 & 100.0 \\
\hline
\end{tabular}

these compounds was formed via orbencarb sulfoxide. The mechanism for the formation of these compounds was discussed previously ${ }^{21}$. Among the metabolites identified in the seedlings, the $S$-(2-chlorobenzyl)-L-cysteine derivatives seemed to be transient metabolites in the plants because the compounds did not appear as major metabolites in a long term metabolism study of orbencarb in soybean plants ${ }^{9}$. Since the same metabolites were detected in all plants, the meta- bolic pathways of orbencarb were suggested to be the same qualitatively in each plant species.

Herbicidal selectivity of orbencarb between crops and weeds has been studied. TАKAHASH and IsHIzuKA ${ }^{20)}$ reported that the difference of absorption of orbencarb between crops and weeds was one of the factors in the herbicidal selectivity of the herbicide. The same authors ${ }^{20)}$ also concluded that the dissipation of orbencarb in wheat and crabgrass seedlings was similar in the two 


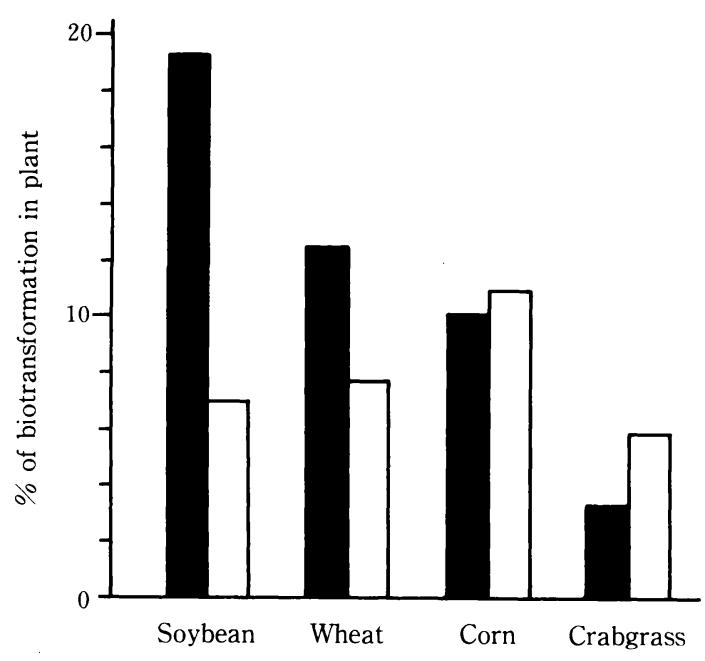

Fig. 3 Percent of biotransformation to $S$-(2)-chlorobenzyl)-L-cysteine derivatives and sum of 2 chlorobenzyl alcohol and 2 -chlorobenzoic acid $96 \mathrm{hr}$ after treatment of ${ }^{14} \mathrm{C}$-orbencarb

— $S$-(2-chlorobenzyl)-L-cysteine derivatives

$\square$ : 2-chlorobenzyl alcohol and '2-chlorobenzoic acid

plants when orbencarb was applied by foliar application. Therefore, the difference in metabolism between the plant species is not an important factor in the herbicidal selectivity of orbencarb, although they did not mention the formation of $S$-(2-chlorobenzyl)-L-cysteine derivatives. In this study, the possibility is suggested that the conjugation reaction of 2-chlorobenzyl moiety of orbencarb may be another factor of herbicidal selectivity, because a distinct difference was observed in the rate of conjugation reaction with the 2-chlorobenzyl moiety of orbencarb among the plant species. Further study on the dissipation of the conjugates is required to support this hypothesis.

\section{Summary}

Metabolism of orbencarb (S-2-chlorobenzyl $N, N$-diethylthiocarbamate) in soybean, wheat, corn and crabgrass seedlings was studied under laboratory conditions. When [phenyl- $-{ }^{14} \mathrm{C}$ ] orbencarb was applied to the roots of each plant, radiocarbon derived from ${ }^{14} \mathrm{C}$-orbencarb was distributed throughout the whole plant for $96 \mathrm{hr}$. In seedlings, the degree of radiocarbon movement to newly developed leaves in soybean was greater than that in wheat, corn or crabgrass.

As metabolites, sixteen compounds were tentatively identified by thin layer co-chromatography with the authentic compounds as free or methyl esters. Four plant species converted the 2-chlorobenzyl moiety of orbencarb to $S$-(2-chlorobenzyl)-L-cysteine, $S$-(2-chloroben$z y l)-N$-malonyl-L-cysteine and its sulfoxide. The amounts of the cysteine containing metabolites based on the radioactivity in plants were 19.3, $12.5,10.1$ and $3.3 \%$ for soybean, wheat, corn and crabgrass, respectively, while the conversion to other major metabolites such as 2-chlorobenzyl alcohol and 2-chlorobenzoic acid showed a similar tendency in all plants. Since the same metabolites were detected in all plants, the metabolic pathway of orbencarb was suggested to be the same in each plant, and the formation of $S$-('2chlorobenzyl)-L-cysteine derivatives was one of these important metabolic pathways.

Acknowledgements: The authors wish to express their thanks to Professor K. Ishizuka of Tsukuba University for his encouragement in this study.

\section{References}

1) Carringer R.D., C.E. Rieck and L.P. Bush: Weed Science 26, 157 160 (1978).

2) Casida J.E., R.A. Gray and H. Tilles: Science 184, 573 574 (1974).

3) Casida J.E., E.C. Kimmel, H. OhKawa and R. Oнкаwa: Pestic. Biochem. Physiol. 5,1 11 (1975).

4) Chen Y.S., I. Schuphan and J.E. Casida: J. Agric. Food Chem. 27, 709 712 (1979).

5) DeBaun J.R., D.L. Bova, K.A. Finl.ey and JJ. Menn: J. Argic. Food Chem. 26, 1098 1104 (1978).

6) Horvath L. and A. Pulay: Pestic. Biochem. Physiol. 14, 265 270 (1980). 
7) Hubbel.L. J.P. and J.E. CAsil)a: J. Agric. Food Chem. 25, 404 413 (1977).

8) Ineida M., T. Unai and C. Tomizawa:J. Pesticide Sci. 11, 85 96 (1986).

9) Ineida M., T. U.ral and C. Tomizawa:J. Pesticide Sci. 11, $97 \sim 110$ (1986).

10) Inlida M., T. Uvaland C. Tomizawa: J. Pesticide Sci. 11, 379 385 (1986).

11) Ishikawa K., I. Okiba and S. Kumatsika: Agric. Biol. Chem. 37, 165 173 (1973).

12) Ishikawa K., Y. Nakamira and S. Ki'watsika: J. Pesticide Sci. 1, 49 57 (1976).

13) Lamol'relix G.L. and D.G. Rl'sness: "Pesticide Chemistry, Human Welfare and the Environment" ed. by J. Miyamoto and P.C. Keakney, Vol.3, IUPAC, Pergamon Press, Oxford, 295 300 (1983).

14) Lay M. M. and J.E. Casida: Pestic. Biochem. Phy- siol. 6, 442 456 (1976).

15) LaY M. M. and J.J. MenN: Xenobiotica 9, 669 673 (1979).

16) Nakamura Y., K. Ishihawa and S. Kumatsikia: Agric. Biol. Chem. 41, 1613 1620 (1977).

17) SANTI R. and F. Gozzo: J. Agric. Food Chem. 24, $1229 \sim 1235$ (1976).

18) Schuphan I. and J.E. Casida: J. Agric. Food Chem. 27, 1060 1067 (1979).

19) SChIPhan I., J.D. Rosen and J.E. Casida: Science 205, 1013 1015 (1979).

20) TAKAHASH A. and K. Ishiz'Ka: Weed Res. Japan 30, 21 29 (1985).

21) Unai T., M. Ikeina and C. Tomizawa: Weed Res. Japan 31, 228 237 (1986).

(Received March 6, 1986)

\title{
除草剤オルベンカルブのダイズ，コムギ，トウモロコシ \\ 及びメヒシバ幼苗における代謝
}

\author{
池田光政・右内忠昭 クミアイ化学工業(㑣生物科学研究所 \\ 富澤長次郎 農業環境技術研究所農薬動態科
}

\begin{abstract}
摘要
${ }^{14} \mathrm{C}$ 標識した orbencarb を用い, ダイズ,コムギ,トウモロコシ及びメヒシバ幼苗における代謝を検討した。2.5ppm 水耕液に 4 種植物の根部を浸し96時間栽培した。 ${ }^{14} \mathrm{C}$ は植物に徐々に吸収され, 植物全体に移行した (Fig. 2)。植物間 で新葉に移行する ${ }^{11} \mathrm{C}$ の割合はダイズが最も高かった。植物を含水メタノールで磨砕抽出後, ジクロロメタンー水分 配を行うと, ジクロロメタン層に未変化の orbencarb, orbencarb sulfoxide, desethyl-orbencarb, $N$-vinyl-orbencarb, $N$ - $\beta$-hydroxyethyl-orbencarb, 4-OH-orbencarb, 5-OH-orbencarb, 2-chlorobenzyl alcohol, 2-chlorobenzoic acid, methyl 2-chlorobenzylsulfide, methyl 2-chlorobenzylsulfoxide, methyl 2-chlorobenzylsulfone, $S$ (2-chlorobenzyl)-N-malonyl-L-cysteine, $S$-(2-chlorobenzyl)- $N$-malonyl-L-cysteine sulfoxide が，水層に $S$ (2-chlorobenzyl)-L-cysteine と 2-chlorobenzylsulfonic acid が合成標品との Co-TLC により同定された（Table 1)。また水層を酵素処理すると，2-chlorobenzyl alcohol と 2-chlorobenzoic acid が遊離され，これら化合物の糖抱 合体の存在が認められた。orbencarb の 2-chlorobenzyl 部は, すべての植物で $S$-(2-chlorobenzyl)-L-cysteine, $S$ (2-chlorobenzyl)-N-malonyl-L-cysteine 及びその sulfoxide (Fig. 1) に代謝され，これら含 cysteine 代謝物の植 物中全放射能に対寸る割合はダイズ，コムギ，トウモロコシ及びメヒシバでそれぞれ 19.3，12.5，10.1 及び 3.3\% であった(Fig. 3)。2-chlorobenzyl alcohol や 2-chlorobenzoic acid 等の他の主要な代謝物の割合は植物間で大きな 差がなかった。4種の植物で同じ代謝物が検出されたことから, orbencarb の代謝経路は植物が 異っても類似して抢 り，S-(2-chlorobenzyl)-L-cysteine 類縁体の生成が主要な代謝経路の 1 つとて推察された。
\end{abstract}

